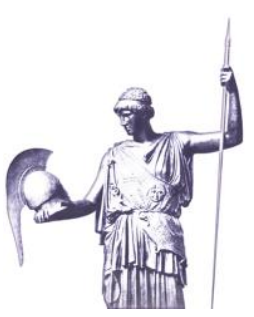

Connections: The Quarterly Journal

ISSN 1812-1098, e-ISSN 1812-2973

Рецензированная статья

М. Ханна, Д. Гранзоу, Б. Болте и Э. Алварадо, Connections QJ 16, № 4 (2017): 5-38

https://doi.org/10.11610/Connections.rus.16.4.01

\title{
Обмен разведывательными данными и инфор- мацией в рамках НАТО: усовершенствование стратегии НАТО для операций по стабилизации и восстановлению
}

\section{Михаэль Ханна, Дэвид Гранзоу, Бьорн Болте и Эндрю Алварадо}

Резюме: Тенденции современного глобального конфликта отдаляют НАТО от его традиционной миссии коллективной обороны в сторону более частых операций по стабилизации и восстановлению (C\&B). Среда С\&B требует, чтобы НАТО взаимодействовало и поддерживало правительства принимающих государств, международные организации и ряд неправительственных организаций с тем, чтобы справляться с проблемами безопасности, политическими и социальными вызовами. Однако, в такой среде НАТО сталкивается с определенными трудностями при сборе и обмене разведывательными данными и информацией. Такая неспособность осуществлять коммуникацию усложняет и без того непростые проблемы, с которыми сталкиваются участвующие субъекты.

В этой статье обозначены три варианта политики, которые могут помочь НАТО усовершенствовать свою поддержку операций по С\&B путем улучшения механизмов по обмене информацией в рамках НАТО и с заинтересованными сторонами вне НАТО. Эти варианты: 1) завершение Федерированной информационной сети для миссий, которая предназначена для агрегирования секретной и несекретной информации в регулируемое виртуальное пространство; 2) формирование доктрины Совместных отделений по сбору и обобщению информации, действующих в качестве клиринговых палат для информации; и 3) создание Региональных координационных центров и команд по стабилизации и восстановлению для реализации конкретных C\&B проектов. 
Развитие этих вариантов политики связано с расширением участия заинтересованных сторон, увеличением эффективности операций и увеличением расходов в целом. На основе анализа плюсов и минусов каждого варианта, мы рекомендуем создание Совместных отделений по сбору и обобщению информации (СОСОИ). Этот вариант дает централизованную структуру для сбора, обработки и распространения информации и разведывательных данных, и нейтральную структуру для осуществления координации между невоенными субъектами. Этот вариант соответствует самому широкому набору выгод для вклада НАТО в C\&B операции как в условиях операций на месте, так и в условиях операций вне зон конфликтов.

Ключевые слова: Операции по стабилизации и восстановлению, разведывательные данные, обмен информации, Федерированная информационная система для миссий.

\section{Проблема и ее значение}

Ключевой проблемой, с которой сталкивается Организация Североатлантического Договора (НАТО) - существующий наиболее длительное время и наиболее успешный многонациональный военный альянс в мире, - является то, как реформировать его структуры обмена информацией так, чтобы они соответствовали сложной оперативной среде, с которой столкнется НАТО в будущем. Этот, казалось бы, вечный вызов стал еще более сложным после исчезновения первоначального оппонента НАТО, Советского Союза. Поскольку НАТО не проводило никаких военных операций во времена Холодной войны, оно никогда на деле не сталкивалось с необходимостью обмениваться информацией в условиях сценария быстро развивающегося конфликта. Однако, после 1991 года, НАТО приходилось много раз мобилизовать себя в ответ на новые угрозы и ситуации, которые требовали надлежащего потока информации.

Сегодня европейские члены НАТО сталкиваются с невиданным набором угроз безопасности, начиная от реваншизма России и заканчивая потоком беженцев из Ближнего Востока и Африки. Операции НАТО были весьма разнообразными, включая обеспечение безопасности и восстановление в Косово и в Афганистане, подготовка вооруженных сил и полицейских для Африканского союза (АС) и иракского правительства, ликвидация последствий природных бедствий на Гаити, в Пакистане и в Соединенных Штатах, операции по борьбе с пиратством у побережья Африканского рога и в Индийском океане и оказание гуманитарной помощи членам Союза Независимых Государств. ${ }^{1}$ Все эти случаи оперативной среды требуют, чтобы НАТО вышло за пределы структур времен Холодной войны, которые ограничивают обмен информацией.

1 NATO, “Operations and Missions: Past and Present," http://www.nato.int/cps/en/ natohq/topics_52060.htm. 
Сегодня угрозы часто предполагают участие акторов, действующих вне официальных правовых органов и органов, занимающихся безопасностью, что требует более комплексного понимания экономических, социальных и политических составных современного конфликта. ${ }^{2}$ Для того, чтобы встречать вызовы безопасности сегодняшнего и завтрашнего дня, НАТО нужно переосмыслить то, как оно обменивается информацией в рамках Альянса и с внешними партнерами. ${ }^{3}$

Нынешние разведывательные структуры Альянса не обеспечивают необходимую способность для обмена информацией. На уровне соединений, формирования НАТО часто имеют недостаточный состав разведывательных органов. ${ }^{4}$ На уровне Альянса не существует центрального органа с полномочиями проверять, расширять полномочия и назначать подотчетность в плане обмена разведывательными данными организациям в рамках НАТО и не-натовским организациям. ${ }^{5}$ Обмен на этом уровне еще более тормозится отсутствием доверия между государствами-членами НАТО. ${ }^{6}$ Способность НАТО обмениваться разведывательными данными и информацией с внешними акторами подобным образом подвергается риску из-за отсутствия доверия и хорошо налаженных механизмов обмена. ${ }^{7}$ Существующие уже механизмы, как правило, используются недостаточно эффективно. ${ }^{8}$

Международное доверие в желание и способность НАТО давать эффективный ответ на международные кризисы ослабевает после операций в Афганистане и в Ливии. А это именно тот тип конфликтов, в которые Альянс и его члены, вероятнее всего, будут вовлечены в будущем. В начале этого десятилетия пять из шести операций НАТО проводились вне территории Альянса. ${ }^{9}$ Как раз для такого вида конфликтов нужно создавать и использовать новые структуры для обмена информацией.

2 Guiding Principles for Stabilization \& Reconstruction (Washington, D.C.: United States Institute of Peace, United States Army Peacekeeping and Stability Operations Institute, 2009), https://www.usip.org/sites/default/files/guiding_principles_full.pdf, 11.

3 "Information Sharing with non-NATO Entities," NATO Joint Analysis and Lessons Learned Centre, November 13, 2012, http://www.jallc.nato.int/products/docs/ factsheet_info_sharing.pdf

4 Интервью с Источником J, представителем США в Союзном корпусе быстрого реагирования НАТО (СКБР), 14 марта 2016.

5 Интервью с полковником Джеймсом Садлером, офицером сухопутных войск при СКБР НАТО, 14 марта 2016.

6 Интервью с Источником А, представителем МО США, 8 марта 2016.

7 Интервью с Источником М, представителем при СКБР НАТО не из США, 15 марта 2016.

8 Stewart Webb, "Improvements Required for Operational and Tactical Intelligence Sharing in NATO," Defence Against Terrorism Review 6, no. 1 (Spring / Fall 2014): 4762, цитата на стр. 59.

9 Ivo Daalder, "NATO's Finest Hour," The Wall Street Journal Europe, September 12, 2011, https://www.wsj.com/articles/SB10001424053111903285704576559422200 245388. 


\section{Недостатки текущей политики НАТО}

В политике НАТО в отношение разведывательных данных нет стандартизованных практик и продуктов, главным образом, из-за требования консенсуса при принятии решений в НАТО. ${ }^{10}$ Внутри НАТО существует множество должностей, связанных с производством и распространением разведывательных данных при низком уровне координации на рабочем и на руководящем уровнях. ${ }^{11}$ Обзор акторов разведывательной деятельности в рамках НАТО, проведенный авторами этой статьи, раскрывает перед нами ландшафт, полный соперничества, политизации и стремления к накопительству, напоминающий состояние разведывательной общности США до 9/11. При отсутствии руководящей политики, обмен информацией в Альянсе остается проблематическим, и у всех организаций имеется мало стимулов делиться информацией. У ведомств есть внутренние правила, запрещающие делиться информацией, и нет поощрений для обмена. Аналитики по вопросам разведки НАТО часто опираются на стандарты производства и раскрытия разведывательных данных своей отдельной страны, преуменьшая значение своевременности и полезности обмениваемых разведывательных продуктов. ${ }^{12}$

У НАТО имеется более развитая политика в отношение обмена информацией со странами-партнерами, не являющимися членами НАТО, и с международными организациями (МO). Часто НАТО использует двусторонние соглашения по обмену, которые включают положения, касающиеся нераскрытия, проверок сетевой безопасности и аппаратной части, предоставления программного обеспечения в некоторых случаях и других мер гарантирования информации. ${ }^{13}$ Поскольку информация, которую НАТО предоставляет этим в некотором роде внешним акторам, не обязательно должна быть действующей, задержки при обмене информации с МО не несут те же риски, что при обмене между военными партнерами. Однако, НАТО продолжает работать над созданием когерентной политики, которая способствовала бы эффективному и продуктивному обмену информацией с неправительственными организациями (НПО).

Неудивительно, что множество НПО не соответствуют строгим требованиям НАТО в плане принципа информационной безопасности «необходимо-знать». Кроме того, хотя НАТО была бы полезна информация с места событий, которой располагают НПО, отсутствие совместного планирования и прямых линий коммуникаций часто делает такую информацию неисполь-

10 Смотри Североатлантический договор, подписанный в Вашингтоне, округ Колумбия, 4 апреля 1949 года, http://www.nato.int/nato_static_fl2014/assets/pdf/ stock_publications/20120822_nato_treaty_en_light_2009.pdf

11 Интервью с Источником J, представителем США при СКБР НАТО, 14 марта 2016.

12 Эти слабости были подчеркнуты в большинстве, если не во всех, интервью, проведенных авторами этой статьи.

13 Интервью с Источником К, представителем МО США, 16 марта 2016. 
зуемой. ${ }^{14}$ И последнее, в операциях по стабилизации и восстановлению (C\&B) НАТО склонно относиться к НПО как к подчиненным, а не как к равноправным партнерам. Это создает неблагоприятные рабочие отношения и приводит к недоверию между НПО и вооруженными силами НАТО. ${ }^{15}$

В итоге можно сказать, что в плане C\&B операций НАТО не смогло создать новую доктрину (или достичь согласия на использование уже существующей) на уровне Альянса. Действительно, в Стратегической концепции НАТО, опубликованной в 2010 году, этот пробел четко указан:

Чтобы быть эффективными по всему спектру менеджмента кризисов, мы должны ... развивать дальше доктрину и военные способности для экспедиционных операций, включая операции по борьбе с повстанцами, стабилизации и восстановлению. ${ }^{16}$

Однако, процесс принятия решений в НАТО консенсусом продолжает мешать прогрессу. Отсутствие общей стратегии, принятой всеми членами Альянса, приводит к тому, что планирование операций часто осуществляется ад хок, в спешке и в условиях неопределенности миссии. ${ }^{17}$ Эти недостатки легко увидеть во всех интервенциях НАТО вне его территории после окончания Холодной войны, включая Косово, Афганистан и Ливию. Без общей для Альянса стратегии, C\&B операции часто страдают от дублирующих и противоречащих друг другу стратегий.

\section{Необходимая для обеспечения C\&B операций информация}

Обеспечение C\&B операции несомненно требует от НАТО работать совместно и при поддержке правительства принимающей страны, соответствующих МО и ряда НПО, чтобы решать широкий круг вопросов безопасности и гуманитарных проблем. Поскольку НАТО еще только предстоит принять или создать комплексную С\&B доктрину, мы используем принцип конечных состояний и межсекторальный принцип, сформулированные в Руководящих принципах стабилизации и реконструкции для описания мероприятий, проведение которых, наиболее вероятно, будет обеспечивать НАТО. ${ }^{18}$

14 Интервью с Источником N, Миссия США при НАТО, 17 марта 2016.

15 Интервью с Михаэлем Клоссоном, вице-президентом по вопросам политики и гуманитарным проблемам, Спасите детей, 18 апреля 2016.

16 Смотри Приложение А.

17 Интервью с доктором Чарльзом (Чаком) Барри, ведущим исследователем Института исследований по национальным стратегическим вопросам Университета национальной обороны США, 20 января 2016.

18 Разработанная Институтом мира Соединенных Штатов (ИМСША) и Институтом миротворческих операций и операций по стабильности Сухопутных войск США (ИМСО) в 2009 году. В Приложении В обрисовывается более детально роль НАТО в C\&B операциях и указываются необходимые для каждого конечного состояния условия. Полную электронную версию можно скачать c http://www.usip.org/sites/ default/files/guiding_principles_full.pdf. 
Это руководство дает общую рамку для работы в сложной среде нестабильности и обозначает общие пробелы и общие вызовы при проведении C\&B операций.

Уничижительный опыт НАТО в Косово и Афганистане ясно показал, что упор надо делать на первенство политических проблем. Принимая стратегии, в которых главная роль отдается военным, НАТО непреднамеренно допускает, чтобы проблемы управления, которые являются источниками нестабильности, оставались без внимания. Чтобы разорвать этот самоподдерживающий себя порочный круг, нужно, чтобы НАТО занялось не только безопасностью, но и начало бы поддерживать С\&B операции под руководством гражданских властей. Таким способом, НАТО будет обеспечивать единую схему строительства административных способностей для правительства принимающей страны, ставя себя в позицию, в которой сможет использовать свои уникальные способности в сборе разведывательных данных и информации и новые технологии командования и управления, стратегической мобильности и коммуникаций.

\section{СТРАТЕГИЧЕСКАЯ РАМКА ДЛЯ СТАБИЛИЗАЦИИ И ВОССТАНОВЛЕНИЯ}

\section{ВЕРХОВЕНСТВО ЗАКОНА \\ - Справедливая правовая рамка \\ - Общественный порядок \\ - Подотчетность закону \\ - Доступ к правосудию \\ - Культура законности}

БЕЗОПАСНАЯ И НАДЕЖНАЯ СРЕДА

Прекращение широкомасштабного насилия

- Общественный порядок

- Законная монополия государства над средствами насилия

- Физическая безопасность Территориальная безопасность

ОБЩИЕ ПРИНЦИПЫ

Собственность и способности принимающей страны

СОЦИАЛЬНОЕ БЛАГОСОСТОЯНИЕ

- Доступ к и предоставление основных услуг

- Доступ к и предоставление образования

- Возвращение и обустройство беженцев и внутренних перемещенных лиц

- Социальное восстановление .

Конечные состояния

Условия
Политические приоритеты Законность

Единство усилий Безопасность

Трансформация конфликтов Региональное участие

СТАБИЛЬНОЕ УПРАВЛЕНИЕ

- Предоставление основных услуг .

Управление государственными

ресурсами

- Политическая умеренность и подотчетность

- Участие гражданского общества
УСТОЙЧИВАЯ ЭКОНОМИКА

- Макроэкономическая стабилизация

- Контроль над теневой экономикой и экономическими угрозами безопасности

- Устойчивость рыночной экономики Создание занятости (n)

() United States Institute of Peace

Фигура 1: Стратегическая рамка для стабилизации и восстановления 


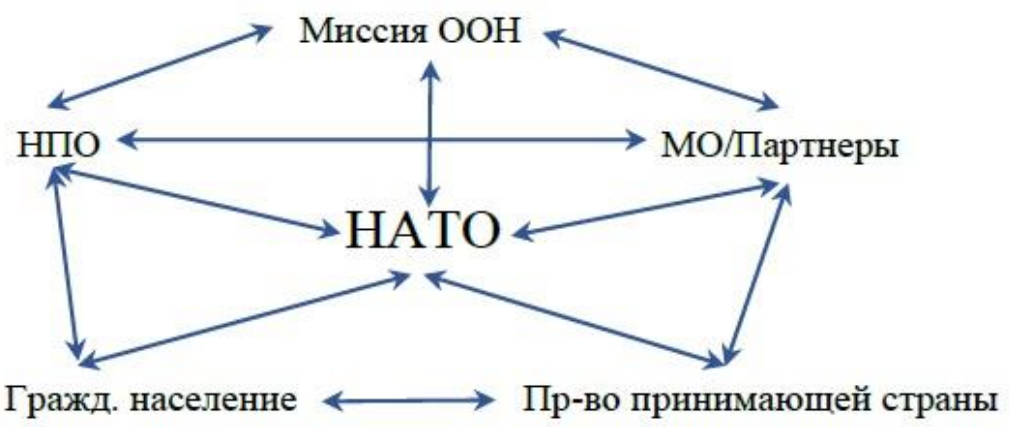

Фигура 2: Отношения НАТО с субъектами, не являющимися элементами НАТО.

Для достижения этой цели НАТО продолжит собирать, анализировать и распространять спутниковую информацию, касающуюся беженцев, внутренних перемещенных лиц (ВПЛ) и других подверженных риску групп населения, поврежденного жилья и критической инфраструктуры, официальных и неофициальных пересечений границ и мест расположения опасных материалов. НАТО будут необходимы устойчивые контакты с НПО, МО, гражданским населением и правительством принимающего государства для получения информации, необходимой для обеспечения успешных C\&B операций.

\section{Варианты для НАТО}

Самые большие вызовы, с которыми столкнется НАТО, будут связаны со степенью, в которой оно может собирать, обрабатывать и распространять информацию не только в рамках самого НАТО, но и среди ряда не натовских субъектов, с которыми НАТО работает совместно для проведения успешных C\&B операций. Выбор НАТО, как оно будет организовать свой вклад, будет иметь разные последствия для миссии в целом. В следующем разделе мы проанализируем три варианта стратегии НАТО в отношение обмена разведывательных данных и информации при C\&B операциях на территории и вне территории Альянса. Варианты представлены в возрастающем порядке: каждый надстраивает предыдущий и требует увеличенных финансовых, материальных и человеческих ресурсов.

\section{Вариант А. Федерированная информационная система для миссий (ФCM)}

Предмет: Пакетная, поставляемая сеть, которая может использоваться одновременно НАТО и его партнерами для обмена секретными разведдан- 
ными, а также МО, НПО и акторами из НАТО для обмена несекретной информацией в общем, минимально регулируемом пространстве.

\section{Описание}

НАТО создало Сеть для афганской миссии (САМ) в 2010 году. Это была федерированная, классифицированная сеть, которая позволяла странам-членам НАТО, предоставляющим контингенты для миссии Международных сил содействия безопасности (МССБ) обмениваться данными и разведывательной информацией. Некоторые не-натовские страны были допущены к САМ на основе двухсторонних соглашений по безопасности. Однако, партнеры по МССБ продолжали мучиться с обменом информации с не натовскими акторами, которые обеспечивали некоторые очень нужные услуги в Афганистане. Попытки использовать несекретные интерфейсы, в том числе Сеть с Доступом для Всех Партнеров (СДВП), Гражданско-военный центр обобщения информации (ГВЦОИ), Защищенный Обмен Информацией (ЗОИ) и RONNA-HarmonieWeb, не решали повторяющиеся проблемы структурных препятствий и отсутствия поддержки. ${ }^{19}$

С того времени НАТО пытается создать гибридную сеть, известную как Федерированная информационная сеть для миссий (ФСМ), которая позволила бы работу с секретной и несекретной информацией в единой сети. ${ }^{20}$ Поскольку ФСМ все еще находится на стадии разработки, в этой работе будет рассказано какие функции и какие соображения следует брать в расчет для конечного продукта:

- Схема маркировки информации, которая позволит регистрированным потребителям вносить информацию по всему спектру классификации информации, и схема менеджмента доступа для ограничения доступа к информации в зависимости от уровня доступа к секретным материалам;

- Архив с послойной структурой и с функцией поиска для хранения классифицированных разведывательных данных на уровнях НАТО строго секретное, НАТО секретное, НАТО несекретное и из открытых источников, соответственно;

- Создаваемая потребителями база данных типа Википедии для несекретной информации с функцией открытого редактирования, регулируемой административной группой НАТО; ${ }^{21}$

19 Интервью с Мелиссой Синклер, бывшей служащей USAID и сотрудником HПO, 7 апреля 2016.

20 Интервью с Жаном-Рене Кутюр, Коммуникационное и информационное агентство НАТО, 17 марта 2016.

21 Такой стандарт, среди всего прочего, должен включать оговорку, что преднамеренные попытки распространять дезинформацию или принятие участия в кибер-вандализме будут приводить к лишению прав на редактирование информации администрацией сайта. 
- Функция чата для всего спектра засекречивания информации для обеспечения прямой коммуникации между потребителями;

- Портал для подачи заявлений в стандартизованной форме, позволяющий субъектам в рамках и вне рамок НАТО подавать заявления на получение информации (ЗНИ) в обоих направлениях; и

- Функция менеджмента финансового фонда для отслеживания пожертвований, сопряжения потребностей и наличных ресурсов с использованием открытой схемы предложения.

В конечном виде информационная сеть будет иметь вид пригодного для поставки готового продукта, который НАТО может использовать в местах неустойчивых ситуаций, и который смогут одновременно использовать как субъекты из НАТО, так и субъекты вне рамок НАТО.

Аргументы «За»

Во-первых, ФСМ сводит множество акторов в общую сеть и обеспечивает разные уровни доступа для проверенных пользователей. Через функцию ЗНИ, ФСМ обеспечивает открытую линию для осуществления коммуникации, хотя и не напрямую, на запрос конкретной информации от НАТО, и наоборот. Как показывает опыт, не все запросы будут удовлетворены, особенно, когда источники и методы получения информации являются особенно чувствительными. Далее, Вики функция создает одноразовую клиринговую палату для несекретной информации и информации из открытых источников, открывая новые каналы для обмена информацией.

Во-вторых, функция менеджмента пожертвований, сформированная по подобию Афганского доверительного фонда восстановления, повысит эффективность распределения ресурсов и ограничит случаи мошенничества. ${ }^{22}$ Такой механизм хранит все зарегистрированные денежные пожертвования на общем счету, управляемом старшим политическим руководством в контексте C\&B, будь это правительство государства, миссия поддержки ООН или другой субъект. Поскольку все субъекты, обеспечивающие операцию по $C \& B$, будут иметь доступ к информации, содержащейся в этом элементе, возможности для дачи взяток, растрат и неправильного использования существенно уменьшатся. Функция Заявления на получение информации (ЗНИ) позволяет местным и иностранным акторам заявлять о своих потребностях, от проектов на восстановление до семинаров на подготовку, а НПО соревноваться на получение ресурсов для удовлетворения конкретных, общепризнанных потребностей.

22 «Афганский доверительный фонд реконструкции (АДФР) был учрежден в 2002 с целью обеспечения скоординированного механизма финансирования бюджета афганского правительства и важнейших национальных инвестиционных проектов. Сегодня АДФР остается самым используемым механизмом для совместного финансирования с малыми расходами на перевод, с высокой прозрачностью и подотчетностью и предоставляет хорошо работающую площадку для обсуждения политики и достижения консенсуса.» Цитата из http://www.artf.af/. 
И последнее, развивая пакетную, поставляемую сеть, НАТО сможет развертывать ФСМ, используя первичный контингент персонала НАТО, отправленный в зону С\&B. С первого дня операции ФМН будет установлена, активирована, и все нефункционирующие элементы будут задействованы по мере развертывания миссии. ФСМ может быть установлена одновременно в разных местах с использованием специализированных коммуникационных систем для раздельного управления операциями. Таким образом, НАТО сможет обеспечивать одновременное проведение множества операций по C\&B, по ликвидации последствий стихийных бедствий, по оказанию гуманитарной помощи и других операций.

\section{Аргументы «Против»}

Наиболее очевидным риском для структуры общей ФСМ сети является ее большая уязвимость к взлому по сравнению с закрытыми сетями. Несмотря на изобилие наличных продуктов для обеспечения сетевой безопасности и на вероятность использования еще более передовых инструментов, зарезервированных для индивидуальных пользователей, угроза взлома по определению выше, чем при физически отделенных сетях. Более того, информация об инциденте с взломом отстает обычно как минимум на несколько часов, что означает, что полученная преступными средствами информация потенциально может быть использована против НАТО прежде, чем Альянс будет извещен о вторжении.

Второй проблемой является способность НАТО спроектировать конфигурацию и профинансировать развитие ФСМ. Нет никакой уверенности, что страны-члены НАТО будут способны достичь консенсуса по техническим спецификациям функций обмена ФСМ. Применяемые в прошлом подходы всегда включали использование отдельных, или герметически изолированных сетей для хранения секретной и несекретной информации, соответственно. Судя по приверженности НАТО к политике централизованного хранения информации в виде записей на бумаге, проистекающая от его неспособности достичь согласия по стандартам хранения информации в цифровом виде ${ }^{23}$ маловероятно, что государства-члены достигнут консенсуса по структуре ФСМ. Так же маловероятно, что все страны-члены НАТО будут иметь желание и будут в состоянии рассекретить информацию для сети, используемой совместно с другими государствами, МО и НПО, с которыми они могут иметь не очень хорошие отношения. Дополнительным препятствием является вопрос, как готовить и как платить аналитикам и сотрудникам по рассекречиванию, которым поставлена задача передвигать информацию между слоями с разной степенью секретности. ${ }^{24}$

И последнее, ФСМ дает техническое решение для гораздо более широкой проблемы обмена информацией. Даже если НАТО придет к согласию

23 Интервью с Кэтрин Герт, начальником архивов и менеджмента информации, штаб-квартира НАТО, 17 марта 2016.

24 Интервью с Кэтрин Герт. 
по ее конфигурации, нет никаких гарантий, что НПО поддержат идею общей сети. Наиболее сомнительным выглядит предположение, что все субъекты, участвующие в операции по C\&B, будут союзниками де факто. Некоторые НПО могут быть готовы предоставлять информацию для сети, но с оговоркой, что определенным странам-членам НАТО или МО будет запрещено видеть эту информацию. Даже участие правительства принимающей страны не гарантировано. Перефразированная строчка из Поля чудес ${ }^{25}$ «Если вы построите ее, они придут», может не быть применимой к созданию ФСМ.

\section{Вариант В. Совместный центр по сбору и обобщению информации}

Предмет: Совместный центр по обобщению информации (СЦОИ) является централизованной структурой, через которую НАТО собирает, обрабатывает и анализирует разведывательные данные и информацию. СЦОИ должен быть в состоянии анализировать как действия идентифицированных угроз, так и информацию о атмосферной ситуации. Функционируя в качестве физической клиринговой палаты, с квалифицированным составом, он является механизмом для организации более целенаправленных гражданско-военных мероприятий.

\section{Описание}

СЦОИ будет укомплектован аналитиками разведывательной информации для одновременной оценки угроз и анализа атмосферной ситуации с благосостоянием, управлением, инфраструктуры и экономики местного населения. ${ }^{26}$ Тогда как аналитики, осуществляющие оценки угроз, будут работать в зоне с ограниченным доступом, те, кто проводит анализ атмосферы, будут работать на местах, встречаясь с активными участниками операций по C\&B. Это позволит персоналу НАТО получить понимание ситуации с первых рук и обмениваться информацией об известных угрозах проектам по С\&B во всей зоне конфликта. ${ }^{27}$ Затем аналитики будут компилировать информацию в содержательные несекретные продукты и распространять их среди самого широкого круга публики, возможно, используя ФСМ. ${ }^{28}$ Эти аналитики будут действовать как «интеграторы информации, засасывая данные, уже собранные военными или гражданскими лицами в публичной сфере и возвращая их обратно в централизованное хранилище». ${ }^{29}$

25 Фильм Universal Studio от 1989 года, режиссер Фил Алден Робинсон.

26 Michael T. Flynn, Matthew F. Pottinger, and Paul D. Batchelor, Fixing Intel: A Blueprint for Making Intelligence Relevant in Afghanistan (Washington, D.C.: Center for a New American Security, 2010), 17-18, www.dtic.mil/dtic/tr/fulltext/u2/a511613.pdf, по состоянию на 12 июня 2017.

27 Flynn, Pottinger, and Batchelor, Fixing Intel, 19.

28 Интервью с Карстен Вестергаард, директор по гражданско-военному сотрудничеству в СКБР НАТО, 15 марта 2016.

29 Flynn, Pottinger, and Batchelor, Fixing Intel, 19. 
Блок аналитиков по разведданным в СЦОИ будет состоять из Национальных ячеек по разведке (НЯР). В состав НЯР будут входить аналитики по разведданным из отдельных стран-членов НАТО (например, итальянская НЯР, испанская НЯР и т.д.). ${ }^{30}$ В идеальном случае, каждая страна НАТО, которая принимает участие в операции по С\&B, будет иметь свою НЯР в СЦОИ, которая будет работать по ФСМ, и в то же время, иметь обратный доступ к национальной разведывательной архитектуре. ${ }^{31}$ Теоретически, СЦОИ мог бы включать еще офицеров по рассекречиванию, чьей единственной задачей было бы облегчать снижение степени секретности национальной разведывательной информации до уровня, позволяющего ее передачу. ${ }^{32}$ Следующий ярус сотрудников будет знать как передавать эту информацию или разведданные из национальных сетей к ФСМ и наоборот, иными словами, поддерживать физическое разделение сетей. ${ }^{33}$ Это будет обеспечивать защиту от утечки.

Недавно НАТО приобрело Систему наблюдения Альянса за наземной обстановкой (САНО), состоящей из пяти беспилотных летательных аппаратов (БЛА) типа «Global Hawk». Этот ресурс позволит СЦОИ собирать и 'свою' разведывательную аэровидеоинформацию (РАВИ), которая является критически важной для отдельных проектов по C\&B, направленных на обеспечение безопасности, ремонт крупномасштабной инфраструктуры, осуществление пограничного контроля и т.д. Какие из стран-членов будут выделять подготовленный персонал для анализа информации, собранной с использованием этих активов, будут намечать меморандумы о взаимопонимании (МВП). ${ }^{34}$ Такие МВП далее будут определять, какими полномочиями располагает командир СЦОИ делиться собранной информацией с членами Альянса, странами не членами НАТО, участвующими в операции по C\&B, и другими внешними наблюдателями.

И последнее, СЦОИ будет иметь физически отдельное и несекретное помещение, в котором руководители НАТО и аналитики разведданных могли бы организовать встречи с гражданскими ведомствами, НПО или частными субъектами. Такое помещение служило бы местом для координационных встреч на высоком уровне между руководством НАТО и другими принимающими участие сторонами. Кроме как для военно-гражданской координации, это сооружение можно было бы использовать как место для проведения дискуссий между правительственными субъектами принимающей страны, НАТО, НПО, гражданскими ведомствами и частными фирмами,

30 Интервью с источником J, 14 марта 2016.

31 Интервью с источником В, неамериканский сотрудник СКБР НАТО, 14 марта 2016.

32 Интервью с источником Р, представитель МО США, 8 марта 2016.

33 Интервью с источником А, представитель МО США, 8 марта 2016.

34 Интервью с полковником Джеймсом Саддлером, заместитель помощника начальника штаба по планированию и политике (G-5) в СКБР, 15 марта 2016. 
обеспечивая полную синхронизацию между всеми заинтересованными сторонами в регионе.

Аргументы «За»

СЦОИ располагает потенциалом выполнять функцию надежной клиринговой палаты между членами НАТО, гражданскими ведомствами, НПО и частными субъектами. Свобода обмениваться информацией, особенно несекретной, позволит субъектам взаимодействовать на беспрецедентном уровне, обеспечивая высокую степень военно-гражданского единства усилий. В прошлых операциях и учениях несекретная платформа для гражданско-военной координации получила высокую оценку участвующих акторов, в частности НПО, так как они находили обмен информацией полезным для их миссий и проектов. ${ }^{35}$ Информация, обмениваемая между союзниками по НАТО, будет создавать общее целостное понимание среды проведения операций по C\&B. ${ }^{36}$

НЯР позволили бы аналитикам разведки взаимодействовать с коллегами-аналитиками из своей страны в безопасной среде. Способность «возвращаться назад» позволила бы развернутым на переднем крае аналитикам требовать комплексные анализы от своих соответствующих национальных разведывательных ведомств. Тогда как близость к другим НЯР создаст среду для взаимодействия между аналитиками НАТО, протоколы физической безопасности будут предотвращать утечку или будут противодействовать прямым попыткам получить доступ к секретной информации. Специализация офицеров по раскрытию и защите информации увеличила бы скорость, с которой производится одобрение на распространение информации в желаемой сети или среди желаемой аудитории. Такие меры уменьшили бы время запаздывания перемещения информации между сетями и повысили бы своевременность разведывательных продуктов. ${ }^{37}$

Возможность НАТО «иметь» больше активов для сбора разведданных уменьшит запаздывание в распространении информации на оперативном и тактическом уровнях. Оперативные командиры НАТО будут иметь доступ к таким ресурсам для сбора данных, как БЛА, которым они напрямую будут ставить задачи по заполнению пробелов в разведданных и будут делиться ими с другими странами-членами НАТО и субъектами, не являющимися частью НАТО, принимающими участие в операциях. Такая способность увеличит полезность разведывательных продуктов НАТО и будет стимулировать обмен информацией между НАТО и субъектами, не входящими в НАТО, предоставляя увеличенную способность для сбора информации всем участвующим в операциях.

35 Интервью с Карстен Вестергаард, директор по гражданско-военному сотрудничеству в СКБР НАТО, 15 марта 2016.

36 Интервью с источником А, представитель МО США, 8 марта 2016.

37 Интервью с источником К, представитель МО США, 16 марта 2016 
Аргументы «Против»

Одним из главных препятствий для успешной реализации модели СЦОИ является нахождение соответственно подготовленного персонала для развертывания на месте. Если одновременно будут развернуты множество разведывательных подразделений НАТО, они окажутся существенно недоукомплектованными в плане наличия разведывательных аналитиков и другого состава для выполнения критически важных функций. ${ }^{38}$ Поэтому СЦОИ может оказаться без достаточного числа людей для проведения необходимых анализов. С такой нехваткой личного состава будет трудно справиться, особенно в случае возобновления угрозы со стороны России. По мере того, как Россия становится все большей заботой для членов НАТО, все менее вероятно, что небольшие страны-члены будут предоставлять личный состав для работы в зоне и вне зоны операций по C\&B, перекладывая этот груз на более богатые и крупные члены НАТО.

Другим препятствием является продолжающееся нежелание стран делиться информацией. Хотя страны-члены и страны, не являющиеся членами НАТО, с большей готовностью будут делиться несекретной информацией в ходе операций по C\&B, все равно будет иметь место определенная нерешительность делиться разработанными разведывательными продуктами. Это во все большей степени верно для Соединенных Штатов, где утечка разведданных из-за Брэдли Мэннинга и Эдварда Сноудена привела к ужесточению доступа к обмену разведданными. Сегодня, профессионалы разведки часто предубеждены к обмену информацией из-за боязни нарушить федеральные законы или способствовать утечке разведданных. ${ }^{39}$

К нерешительности для обмена добавляется медленность процесса, в результате которого многие страны члены допускают раскрытие разведданных. У США очень либеральная политика в сфере обмена информацией в смысле предоставления нижним эшелонам полномочий на обмен информацией, по сравнению с многими другими странами-членами НАТО. Действительно, многие страны-члены НАТО не имеют профессиональных специальностей в военной разведке, а те, которые имеют, часто не имеют стандартов для раскрытия данных иностранным государствам. В результате этого, аналитики склонны к чрезмерной степени засекречивания своей работы. Когда их просят об обмене разведывательными продуктами, аналитики, у которых нет подготовки для раскрытия информации, обязаны просить разрешения от своих национальных ведомств. Время, которое зани-

38 Интервью с источником L, неамериканский представитель СКБР НАТО, 14 марта 2016.

39 Anna-Katherine Staser McGill and David H. Gray, "Challenges to International Counterterrorism Intelligence Sharing," Global Security Studies 3, no. 3 (2012): 76-86, цитата на стр. 83-84. 
мает этот процесс, часто делает запрашиваемую информацию уже бесполезной. ${ }^{40}$

Получение согласия НПО тоже является большой проблемой. Создание СЦОИ само по себе не станет стимулом для НПО делиться информацией с НАТО. По результатам некоторых исследований, НПО и другие гражданские ведомства готовы работать с силами НАТО, только если они почувствовали пользу от обмена информацией. Такой обмен информацией не только помогает создать более надежную среду безопасности, но и улучшает координацию между ними и другими организациями и ведомствами для эффективной реализации проектов.

\section{Вариант С. Региональные координационные центры и Группы по стабильности и восстановлению}

Предмет: Региональный координационный центр (РКЦ) и Группы по стабильности и восстановлению (ГСВ) будут координировать гражданско-военную работу на региональном уровне. Задачей ГСВ является работа по восстановлению в зоне ответственности РКЦ.

\section{Описание}

Модель Регионального командования (РК) была использована в Афганистане для координирования всей региональной гражданско-военной деятельности, осуществляемой военными элементами ПГВ в зоне их ответственности под контролем МССБ. ${ }^{41}$ Каждое РК располагает компонентом для командования и управления, который обеспечивает логистическую поддержку гражданских проектов в зоне ответственности РК. Подэлементы РК, Провинциальные группы по восстановлению (ПГВ) были «совместными гражданско-военными организациями, которые способствовали прогрессу в управлении, безопасности и восстановлении». ${ }^{42}$ На оперативном уровне, РК создало линии координации усилий между гражданскими ведомствами, частными фирмами, НПО и МССБ. На тактическом уровне ПГВ осуществляли деятельность по С\&B - строительство школ, полицейских участков, ремонт инфраструктуры и другие проекты. ${ }^{43}$

Изменение наименования на Региональный координационный центр и Группы по стабильности и восстановлению является отражением понимания, что в операциях по C\&B преимущество следует отдавать политическим

40 Интервью с источником В, неамериканский представитель СКБР НАТО, 15 марта 2016.

41 ISAF Regional Command Structure, October 22, 2009, по состоянию на 10 июня 2017, http://www.nato.int/ISAF/structure/regional_command/.

42 Robert Perito, U.S. Experience with Provincial Reconstruction Teams in Afghanistan: Lessons Identified, Special Report 152 (U.S. Institute of Peace, October 2005), 6.

43 Kristian Fischer and Jan Top Christensen, "Improving Civil-Military Cooperation the Danish Way," NATO Review (Summer 2005), https://www.nato.int/DOCU/review/ 2005/Peace-Building/civil-military-cooperation-Danish/EN/index.htm. 
соображениям, а не военным результатам. Однако, сохранение организационной структуры, подобной той, какую имела модель РК, близость к акторам и тесная координация обеспечивают наличие среды, подходящей для обмена информацией. Такая близость подразумевает такие совместные действия, как ежедневные инструктажи, внутриведомственные требования к подчиненности и неформальный обмен информацией. Кроме того, НАТО не следует пытаться подчинить НПО и других акторов, не являющихся членами НАТО, а интегрировать их уникальные умения и ресурсы в общую работу. Это учитывает нейтральное пространство между политическими и военными целями, занимаемое часто НПО.

Аргументы «За»

Отношения между силами НАТО и НПО, устанавливаемые моделью РКЦ и ГСВ, были бы взаимовыгодными. Безопасность и логистические способности, обеспечиваемые РКЦ, будут позволять гражданским ведомствам, НПО и даже частным предприятиям вести свои операции в условиях безопасности, обеспечиваемой силами НАТО. В свою очередь, работа по администрированию и восстановлению гражданских ведомств, НПО и частных субъектов могла бы создавать более надежную и стабильную среду. Тесная близость акторов будет способствовать тому, что информация, имеющая отношение к безопасности и общей атмосфере ситуации, обменивалась бы между силами НАТО и гражданскими субъектами. Силы НАТО могли бы координировать использование логистических способностей между военными и гражданскими субъектами, а также облегчали бы координацию между ними с использованием коммуникационных технологий.

Пример такого обмена информацией имел место в 2011 году, когда штаб-квартира 82-й воздушно-десантной дивизии начала исполнять функцию РГ Юг. В то время штаб и подчиненные ему силы были сосредоточены на борьбе с силами движения Талибан в регионе, и на содействие операциям по восстановлению оставалось мало военного персонала. Однако, ПГВ, действующие в том районе, предоставляли очень ценную информацию относительно инфраструктуры, социального благосостояния и администрирования в районах, где у сил МССБ не было достаточно личного состава для проведения операций. Подобным образом, штаб дивизии мог передавать информацию ПГВ и НПО, касающуюся среды безопасности, необходимость, которая проистекала от уровня насилия, имевшего место в том районе в то время. $^{44}$

Концепция РКЦ позволяет НАТО использовать некоторые из наиболее гибких возможностей своей структуры для обмена разведданными. Хотя НАТО может быть основным поставщиком безопасности для операций по C\&B, вовлечение других стран, не являющихся членами НATO, потребует их включение в работу по планированию и обмену информацией. Командир РКЦ может способствовать подписанию соглашений по гарантированию

44 Интервью с источником А, представитель МО США, 8 марта 2016. 
безопасности, которые будут очерчивать границы в рамках, в которых страны, не являющиеся членами НАТО, смогут получать и использовать предоставляемые разведданные. ${ }^{45}$ То же относится и к НПО; командир РКЦ имеет полномочия делиться информацией с любой стороной, которой она может быть полезна. Предоставление правомочий командиру РКЦ одобрять обмен разведданными и информацией обходит иначе длительный бюрократический процесс и позволяет ему управлять доступом к разведданным и информации в соответствие с включением и исключением субъектов в проведение операций по C\&B. ${ }^{46}$

\section{Аргументы «Против»}

Концепция РКЦ не способствует единству гражданско-военной работы на национальном уровне. Наоборот, каждый РКЦ находится под руководством отдельной страны-члена НАТО, подчиняя операции и обмен информацией предполагаемым потребностям военным и политическим приоритетам этой конкретной страны. В Афганистане «Американские ПГВ имели численность менее 100 человек и были сосредоточены на защите сил и на проектах, имевших быстрое воздействие ... британские ПГВ были несколько больше, ставили акцент на реформу афганского сектора безопасности и помогали смягчать противостояние между соперничающими полевыми командирами ... ПГВ Германии имели более 300 человек и были строго поделены между своим военным и серьезным гражданским компонентом». ${ }^{47}$ При отсутствии центрального органа для руководства РКЦ, каждая индивидуальная ПгВ будет иметь успех или не иметь успеха скорее благодаря случайности, а не в результате реализации стратегии. ${ }^{48}$

Модель РКЦ не обеспечивает содействие НПО, в частности тех, кто хочет сохранять видимость нейтралитета или чья репутация зиждется на их независимости от вооруженных сил. Более крупные НПО осуществляли координацию с НАТО на уровне РК и, возможно, будут продолжать делать это и в будущем. Другие будут возражать против сотрудничества с РКЦ в будущих операциях из-за неотьемлемых опасений относительно нейтралитета. РКЦ потенциально может быть заторможен обременяющим числом акторов, что затруднит эффективную гражданско-военную координацию. Далее, нет никаких гарантий, что более мелкие субъекты осознают, как следует взаимодействовать с РКЦ, в случае чего небольшие субъекты могут подвергнуть себя и своих членов риску. 49

45 Интервью с Катериной Герт, 17 марта 2016.

46 Интервью с источником С, неамериканский представитель СКБР НАТО, 15 марта 2016.

47 Perito, U.S. Experience with Provincial Reconstruction Teams, 3.

48 Michael J. McNerney, "Stabilization and Reconstruction in Afghanistan: Are PRTs a Model or a Muddle?" Parameters 35, no. 4 (Winter 2005-06): 32-46.

49 Интервью с источником А, представитель МО США, 8 марта 2016. 


\section{Выводы}

НАТО показало, что понимает проблемы, связанные с обменом информации со странами-членами НАТО и странами, не являющимися членами НАТО, и ведет работу по их разрешению. Путем проб и ошибок НАТО создало множество ад хок программ и механизмов обмена информацией во время кризисов. Несмотря на это, многие общие препятствия остаются. Обмен разведданными в рамках альянса остается проблематическим, и ни у кого нет стимула делиться информацией. У ведомств есть внутренние правила, направленные против обмена информацией, и обмен информацией ничем не поощряется. Для индивидуального аналитика раскрытие информации иностранным партнерам подвергает риску его благополучие.

Хотя НАТО и НПО действуют все более совместно на таких театрах, как Косово и Афганистан, барьеры для эффективного обмена информацией продолжают действовать. Силы НАТО сталкиваются с трудностями при взаимодействии с партнерами «по случаю», которые появляются из сообщества НПО при инициировании операции по С\&B. Некоторые НПО, действительно, уже работали в данном районе в течение нескольких лет или могут преследовать цели, которые не согласуются с общими задачами операции по С\&B. Множество НПО просто не решаются взаимодействовать с вооруженными силами, поскольку это может скомпрометировать их нейтралитет и доверие к ним. ${ }^{50}$ Однако, так как НПО чувствуют, что они получают ценную информацию в результате информационного обмена, они со все большей вероятностью готовы сотрудничать с НАТО.$^{51}$ Более того, НПО приходят к пониманию, что все больше мест в мире становятся враждебно настроенными, даже к НПО. 52 В обстановке нарастающих угроз для НПО увеличивается необходимость устанавливать отношения между ними и НАТО. И наконец, НАТО и военные формирования четко должны перестать воспринимать НПО в качестве факторов повышения эффективности и необходимым условием для успешности своих действий. Это ослабляет НПО и искривляет их заявленную нейтральность. ${ }^{53}$ Наоборот, НАТО должно рассматривать НПО в качестве партнеров и устанавливать взаимовыгодные отношения с ними.

Тогда как у США и Соединенного королевства имеются профессиональные разведывательные органы в рамках их военных структур, у других членов НАТО таких органов нет. Для многих стран эта проблема проистекает от нехватки ресурсов, финансовых или просто от отсутствия соответствующих способностей для сбора информации, которые оправдывали бы существование военных разведывательных органов. Чтобы компенсировать эту нехватку профессионалов разведки, члены Альянса часто назначают на такие

50 Интервью с Мелиссой Синклер, бывший сотрудник USAID и HПO, 7 марта 2016.

51 Интервью с Карстен Вестергаард, директор отдела по гражданско-военному сотрудничеству, СКБР НАТО, 15 марта 2016.

52 Интервью с Мелиссой Синклер, бывший сотрудник USAID и HПО, 7 марта 2016.

53 Интервью с Майклом Клоссон, Спасите детей, 18 апреля 2016. 
должности офицеров и сержантов из других служб (пехотинцев, инженеров, летчиков-истребителей), причем их первое назначение на разведывательную работу имеет место на позднем этапе их карьеры. Хотя эти офицеры и сержанты являются интеллигентными и способными людьми, у них нет опыта сбора, анализа и распространения разведданных. Это замедляет темп обмена разведданными, поскольку эти люди должны сначала ознакомиться со своей собственной архитектурой разведки и с правилами обмена информацией. ${ }^{54}$

Множество стран-членов НАТО имеют каскадный бюрократический процесс разрешения публикации или снижения степени секретности национальных разведывательных продуктов. Такой медлительный процесс часто приводит к тому, что разведанные теряют свою своевременность. Большинство стран НАТО не имеют должностей, эквивалентных должности Офицера по раскрытию информации иностранным контрагентам (ОРИ), которые знают правила работы с засекреченной информацией и все их сложности. ОРИ знает информацией какого уровня секретности можно делиться с другими странами и как раскрывать несекретные части секретных продуктов. Однако, процесс подачи заявки на получение правомочий на обмен информацией от внешнего ведомства все равно может быть достаточно долгим.

\section{Рекомендации}

Обзор аргументов «За» и «Против», связанными с тремя вариантами, выделяет Совместный центр обобщения информации (СЦОИ) в качестве оптимального выбора НАТО для расширения обмена информацией и разведанными. Хотя каждый вариант основывается на других, недостатки в широте политики и препятствия перед формированием доктрины в вариантах ФСМ и РКЦ, соответственно, уменьшают их полезность для НАТО в доктринальном плане. СЦОИ дает определенные пользы для способности НАТО обеспечивать проведение операций по С\&B как на собственной территории, так и вне ее.

Между операциями на территории НАТО и операциями на других территориях имеются отличия, которые стоит упомянуть. При операциях на территории стран НАТО характерно то, что имеются опасения относительно суверенитета и нежелание принимающей страны (члена НАТО) передавать полномочия внешним акторам. Такая динамика может мешать усилиям по координации. Далее, включение принимающей стороны в соглашения по обмену информацией в потенциале имеет существенную внутреннюю политическую цену. Обмен информацией при операциях вне территории НАТО может оказаться более легким из-за относительного отсутствия проблем с суверенитетом для стран-членов НАТО. Однако, опасения стран-членов НАТО в плане защиты источников и методов все равно могут затруднять

54 Интервью с источником М, неамериканский представитель в СКБР НАТО, 15 марта 2016. 
обмен информацией между партнерами. Кроме того, плохие отношения между странами-членами НАТО и другими заинтересованными сторонами иногда могут помешать обмену информацией. Учитывая увеличивающиеся опасения среди некоторых из восточных стран-членов НАТО в отношение гибридных угроз со стороны России, их поддержку может получить доктрина, которая была бы применимой как для операций на территории стран-членов НАТО, так и для операций на других территориях.

\section{Защита}

Создание СЦОИ является единственным вариантом с разумным шансом на развитие в доктрину обмена информацией. Как чисто технический вариант, ФСМ самостоятельно не может дать членам НАТО соответствующего регламента и соответствующих процессов для обмена информацией при операциях по C\&B. Хорошая сеть не решает проблемы, связанные с нехваткой обученного разведывательного персонала. А также не гарантирует, что информация, проходящая через сеть, будет пригодной для своевременного использования. Тенденция к присваиванию излишне высокого уровня секретности, отсутствие стимулов для подключения к сети и другие присущие этому варианту препятствия не могут быть преодолены через простое расширение пропускной ленты обмена.

С другой стороны, концепция РКЦ в качестве варианта доктрины будет излишне утяжеленной, поскольку на нее сильное влияние оказывает контекст: разные географические обстоятельства будут требовать учет разных соображений и использование конкретных моделей РКЦ. К примеру, модель РКЦ, развернутого для операций по С\&B на южной периферии НАТО, не обязательно будет подходящей для таких операций на восточной периферии НАТО. По тем же причинам НАТО столкнется с трудностями при включении РКЦ в доктрину, которую можно было бы применять одновременно для операций на территории стран НАТО и на территории стран, не являющимися членами НАТО.

Следование концепции СЦОИ предоставит НАТО улучшенные процессы обмена информацией как в рамках, так и вне рамок альянса во время операций по С\&B. В качестве единого центра с персоналом, специализированным в предоставлении информации и обеспечении физической раздельности сетей, СЦОИ располагает механизмами для стимулирования информационного потока между членами НАТО и для защиты от непреднамеренных утечек. Включение внешних мест для встреч лицом к лицу с НПО и МО также может способствовать передаче информации между военными и невоенными субъектами, принимающими участие в операциях по С\&B. Поскольку СЦОИ будут функционировать в любое время, они будут квалифицировать корпус аналитиков, знакомыми с анализом целостной атмосферы и с движением разведданных.

Преимуществом СЦОИ является их гибкость, развертываемость и возможность воздерживаться от действий, компрометирующих разведку или 
суверенитет принимающего государства. Физический риск утечек или шпионажа существенно уменьшается в результате использования модели НЯР, при которой только личный состав из соответствующего государства может иметь физический доступ к национальным сетям разведданных и информации. Кроме того, наличие подготовленных офицеров по предоставлению информации иностранным субъектам будет гарантировать, что НАТО и другим партнерам будут предоставляться только разрешенные разведданные.

\section{Ответ на контраргументы}

Принятие решения с консенсусом потенциально может ослабить роль и возможности СЦОИ, что сделает эти центры менее действенным активом НАТО в операциях по С\&B. Однако, у НАТО уже есть опыт создания СЦОИ, в качестве которых можно рассматривать Центр НАТО по обобщению разведданных (ЦНОРД). Предназначенный для функционирования в операциях вне территории стран НАТО, ЦНОРД консолидирует разведывательную работу стран-членов на одной территории. ЦНОРД служит примером факта, что государства члены НАТО могут и будут обмениваться разведданными в рамках определенных структур безопасности. На данный момент отсутствует способность обмениваться информацией с НПО и другими субъектами вне стран-членов НАТО.

НПО могут воздерживаться от обмена с СЦОИ из-за опасений в плане своего нейтралитета, что ограничивает количество и качество обмениваемой информации. Для улучшения ситуации в этой сфере будет нужно руководству НАТО более подробно ознакомиться с потребностями НПО. Несмотря на это, некоторые качества СЦОИ способствуют улучшению сотрудничества между этими двумя сторонами. Нейтральное место для встреч СЦОИ между аналитиками и гражданскими группами, работающими в стране, может помочь установлению близости между обеими сторонами. Неоднократные встречи лицом к лицу могут дать лучшее понимание возможностей и опасений НПО со стороны НАТО и наоборот. Информация, обмениваемая через СЦОИ, будет взаимовыгодной и будет способствовать созданию восприятия равенства между НПО и НАТО. Более близкое знакомство и тесная коммуникация улучшит способность обеих сторон реагировать в сложных операциях по С\&B.

Качество информации и разведданных, распространяемых через СЦОИ, может пострадать, если некоторые участвующие страны-члены НАТО откажутся делиться информацией. Сбор данных является одной из важнейших задач каждого разведывательного ведомства, и защита способностей оперативных работников, БЛА и сенсоров имеет огромное значение. Национальные ячейки по разведданным в СЦОИ предназначены для ускорения этого процесса через квалификацию офицеров по предоставлению разведданных, через создание отношений между личным составом на месте и через предоставление возможности получать обратную связь. Однако, сам по себе СЦОИ вряд ли может преодолеть национальную склонность защищать 
источники и методы. Это препятствие можно было бы смягчить назначением гражданского директора НАТО по разведке, как это описано в Приложении С. Такая должность могла бы быть фактором на высшем уровне руководства, который защищал бы расширение и реформирование обмена разведданными.

\section{Реализация}

Наиболее насущной задачей для НАТО является разработка требований к личному составу и оборудованию СЦОИ. Эти требования могут быть определены на основании представлений нынешних начальников разведки и других офицеров штабов о том, какими должны быть эти требования. Поскольку люди на разных должностях сформулируют разные требования, штаб-квартире НАТО в Брюсселе будет нужно определить основные требования к персоналу и экипировке для создания СЦОИ. И последнее, НАТО надо будет выполнить оценку расходов и потребовать от стран-членов выполнить требования по оборудованию и расквартированию.

Основываясь на исследованиях авторов, вероятно, СЦОИ потребует приблизительно 100-120 человек разведывательного персонала. Однако, число личного состава может увеличиться по мере подключения большего количества стран к операции. В их число будут входить аналитики по разведке из всех источников, электронной, визуальной и агентурной разведке. Кроме того, должны иметься специалисты по установлению и поддержанию гражданско-военных отношений как с невоенными правительственными органами, так и с НПО. Далее, СЦОИ нужно обеспечить автономность в плане электропитания, транспортных средств и палаток. Это оборудование будет стоить около 45 миллионов долларов США, и стоимость будет увеличиваться по мере того, как СЦОИ будет создавать новые постоянные сооружения для операций.

Прежде чем ввести СЦОИ в доктринальные документы, НАТО следует после полного укомплектования и приведения в работоспособное состояние подвергнуть СЦОИ испытательному периоду в течение двух лет. Рекомендуется двухлетний период из-за трудностей, связанных с подготовкой аналитиков по разведданным, созданием стандартных оперативных процедур и достижением общего понимания и привыкания к конкретным обязанностям и ответственностям. СЦОИ должен быть расквартирован в военном гарнизоне либо при штабе Сил реагирования НАТО (СРН) в Брунссуме или в Неаполе, или при СКБР в Соединенном Королевстве. Двухгодичный испытательный период позволит НАТО установить, где имеется нехватка личного состава или оборудования. Кроме того, он позволит проверить СЦОИ в учениях для определения его жизнеспособности не только с позиций НАТО, но также и с позиций его гражданских партнеров и не государственных акторов.

После двухгодичного испытательного периода НАТО следует оценить жизнеспособность проверяемого СЦОИ и предпринять меры по устранению 
установленных недостатков. После идентификации слабостей НАТО следует кодифицировать требования, роль и ответственности СЦОИ так, чтобы он мог стать составной частью доктрины и процесса планирования НАТО. После кодификации НАТО должно операционализировать один СЦОИ при СКБР и штаб-квартире СРН в Брунссуме и Неаполе. Эти штаб-квартиры идеальны для СЦОИ из-за роли, которую они играют в ответе на кризисы.

Поскольку СЦОИ будет выгоден всем членам альянса, финансирование СЦОИ должно осуществляться из военного бюджета НАТО, который финансируется напрямую странами-членами НАТО. Хотя расходы, связанные с созданием и функционированием СЦОИ, еще не определены на данный момент, оценку расходов будет сравнительно легко осуществить, когда НАТО сформулирует требования по персоналу и экипировке СЦОИ. Тем временем, для начала анализа расходов СЦОИ НАТО может использовать статистику расходов по поддержанию своих существующих штабов.

Как и для всех других финансируемых общими средствами программ, СЦОИ должен быть единодушно одобрен САС. Учитывая, что страны-члены НАТО воспринимают по-разному важность существующих угроз, единодушное одобрение СЦОИ и его финансирования может оказаться сложной задачей. Тогда как некоторые члены НАТО рассматривают операции по С\&B как критически важные для стратегии НАТО, другие воспринимают традиционную конвенциональную угрозу, в частности Россию, в качестве наиболее важной для НАТО и считают, что ей НАТО должно уделять максимум внимания и финансовых ресурсов. По мере того, как страны-члены начнут выполнять свое обещание увеличить свои военные бюджеты до 2 \% от ВВП, финансовые ресурсы НАТО увеличатся до размера, позволяющего обеспечивать мероприятия НАТО по противодействию конвенциональным угрозам, и соответствующим образом планировать проведение будущих операций по C\&B.

\section{Приложение А. Стратегическая концепция НАТО 2010, выдержки по C\&B 55}

- «Это обязывает Альянс предотвращать кризисы, осуществлять менеджмент конфликтов и стабилизировать ситуацию после оконча-

ния конфликта, в том числе работать более тесно с нашими международными партнерами, прежде всего с Организацией Объединенных Наций и Европейским Союзом.» (с. 4)

- «Нестабильность или конфликт вне границ НАТО может напрямую угрожать безопасности Альянса, в том числе порождением экстре-

55 NATO Strategic Concept 2010, http://www.nato.int/strategic-concept/pdf/Strat_ Concept_web_en.pdf. 
мизма, терроризма и такой незаконной транснациональной деятельности, как контрабанда оружия, наркотиков и людей.» (с. 11)

- «Кризисы и конфликты вне границ НАТО могут составлять прямую угрозу для безопасности территории и населения Альянса. Поэтому НАТО будет вмешиваться, когда это возможно и когда это необходимо, с целью предотвращать кризисы, осуществлять менеджмент кризисов, стабилизировать ситуацию после окончания конфликтов и обеспечивать восстановление.» (с. 19)

- «Уроки, извлеченные из операций НАТО, в частности в Афганистане и на Западных Балканах, четко показывают, что для эффективного менеджмента кризисов необходим комплексный политический, гражданский и военный подход. Альянс, вместе с другими международными акторами, активно будет действовать до, в течение и после кризисов с целью стимулировать совместный анализ, планирование и осуществление деятельностей на месте, с тем чтобы максимизировать когерентность и эффективность всех международных усилий.» (с. 19)

- «аже когда конфликт заканчивается, международное сообщество часто обязано продолжать осуществлять поддержку для создания условий для долгосрочной стабильности. НАТО будет иметь готовность и располагать способностями помогать стабилизации и восстановлению, в тесном сотрудничестве и проводя консультации всегда, когда это возможно, с другими подходящими международными акторами.» (стр. 20)

- «Чтобы быть эффективными по всему спектру менеджмента кризисов, мы будем ... далее развивать доктрину и военные способности для экспедиционных операций, в том числе, для борьбы с повстанцами, для операций по стабилизации и восстановлению.» (с. 21)

- «Мы твердо решены развивать дружеские отношения и осуществлять сотрудничество со всеми странами Средиземноморья и намерены и в следующие годы и далее развивать Средиземноморский Диалог. Мы придаем большое значение миру и стабильности в регионе Персидского залива и намерены укреплять наше сотрудничество со Стамбульской Инициативой Сотрудничества.» (с. 30-31)

\section{Приложение В. Руководящие принципы, конечные состояния и необходимые условия}

Надежная и безопасная среда - среда, в которой люди могут вести свою ежедневную жизнь без страха от систематического или широко-масштабного насилия. Это конечное состояние охватывает большинство условий, которым НАТО готово оказывать поддержку. НАТО располагает потенциалом 
обеспечивать подготовку и осуществлять техническую поддержку развития вооруженных сил принимающего государства в ходе их деятельности по разделению враждующих сторон, вести переговоры по прекращению огня и осуществлять программы по разоружению, демобилизации и реинтеграции (РДР). Кроме того, НАТО располагает уникальной способностью транспортировать войска и гуманитарную помощь на территории, где необходима защита населения и инфраструктуры. И последнее, НАТО может предоставлять ресурсы для командования и управления, используя свою Воздушную систему раннего предупреждения и управления (ВСРПУ) для содействия усилиям принимающего государства, направленным на обеспечение безопасности границ и перехвату нарушителей.

Верховенство закона-возможность людей иметь равный доступ к справедливым законам и к системе правосудия, пользующейся доверием, перед которыми ответственны все люди, которые защищают их человеческие права и обеспечивают их спокойствие и безопасность. Как военный союз, на первом месте направленный на коллективную оборону своих членов, НАТО, очевидно, будет в меньшей степени заниматься обеспечением условий, способствующих верховенству закона, чем другими вопросами. Тем не менее, у НАТО огромный опыт в подготовке местных правоохранительных органов и подразделений национальной гвардии в результате его работы в Косово, Афганистане и Ираке. Существует разграничение между такими наиболее важными ответственностями по обеспечению безопасности, которые не присущи полицейским формированиям, как реакция в чрезвычайных ситуациях, обезвреживание боеприпасов и менеджмент опасных веществ. Самое важное то, что, предоставляя поддержку такого рода, НАТО может работать для гарантирования того, что власти принимающей страны начнут уважать человеческие права и привыкнут к прозрачности в применении законов.

Стабильное управление - способность людей участвовать, иметь доступ или состязаться для получения власти в рамках ненасильственных политических процессов и пользоваться коллективными благами и услугами государства. Как и в случае с верховенством закона, направленность НАТО на вопросы безопасности ограничивает его прямое участие в реформировании управления. Стабильное управление, однако, требует государственной монополии над законным применением насилия, которая может быть обеспечена путем реформирования сектора безопасности (РСБ). РСБ не ограничивается подготовкой полицейских формирований для проведения расследований и охраны правопорядка, но включает и работу по укреплению государственного контроля, менеджмента и надзора. Кроме того, НАТО располагает коммуникационными технологиями, необходимыми для обеспечения способности правительства коммуникировать со своим населением. Работа по обеспечению прозрачности в процессе перехода будет способствовать усилиям управления оставаться легитимным в глазах граждан. 


\section{Необходимые условия:}

- Прекращение широкомасштабного насилия является условием, при котором широкомасштабный вооруженный конфликт был приостановлен, воюющие стороны разведены и находятся под наблюдением, мирное соглашение о прекращении огня выполняется и имеется механизм менеджмента нарушений, совершенных с использованием насилия.

- Общественный порядок является условием, при котором законы применяются на справедливой основе; жизнь, собственность, свободы и права людей защищены; уголовное и политическое насилие сведены до минимума; уголовные элементы (грабители, бунтовщики и руководители сетей организованной преступности) преследуются законом, подвергаются аресту и содержатся под стражей.

- Государственная монополия на законное насилие является условием, которое состоит в том, что главные незаконные вооруженные группировки выявлены, разоружены и демобилизованы; силы полиции и обороны подверглись чистке и прошли переподготовку; силы национальной безопасности действуют на законных основаниях под управлением законных государственных властей.

- Физическая безопасность является условием, выражающемся в том, что политические лидеры, бывшие боевики и обыкновенное население освобождены от страха серьезной угрозы их физической безопасности; беженцы и внутренние перемещенные лица могут вернуться в свои дома без страха от карательного насилия; женщины и дети защищены от насилия; ключевые исторические и культурные объекты и критическая инфраструктура защищены от нападений.

- Территориальная безопасность есть условие, состоящее в том, что люди и товары могут свободно перемещаться по стране и через границы без страха за свою жизнь и здоровье; страна защищена от нашествий; границы в разумной мере защищены от проникновения повстанческих и террористических элементов и нелегальной контрабанды оружия, наркотиков и людей.

- Справедливая правовая база является условием, состоящим в том, что законы соответствуют международным нормам и стандартам по правам человека; юридически определены и прозрачны; принимаются в результате прозрачной процедуры; справедливы и защищают все население, а не только правящую элиту.

- Подотчетность перед законом является условием, выражающемся в том, что население, представители власти и лица, совершившие преступления в прошедших конфликтах, ответственны перед законом за свои действия; судебная система независима и свободна от политического давления; существуют горизонтальные и вертикальные механизмы подотчетности, предназначенные для предотвращения злоупотребления властью. 
- Доступ к правосудию есть условие, состоящее в том, что люди могут требовать и получать правовую защиту для своих жалоб в официальных и неофициальных институциях правосудия, которые соответствуют международным стандартам по правам человека, и существует система, обеспечивающая равное и эффективное применение закона, справедливую процедуру и прозрачность.

- Культура законности - это условие, выражающееся в том, что население в целом соблюдает закон и обращается к системе правосудия для удовлетворения своих жалоб.

- Предоставление основных услуг является условием, выражающемся в том, что государство обеспечивает базовую безопасность, верховенство закона, экономическое управление и услуги по удовлетворению основных человеческих потребностей; основные услуги предоставляются без дискриминации и у государства есть потенциал для предоставления основных услуг без существенной помощи международного сообщества.

- Управление государственными ресурсами есть условие, состоящее в том, что национальные и субнациональные институты управления восстановлены, обеспечены финансированием и подотчетным личным составом; сектор безопасности реформирован и приведен в подотчетность гражданскому контролю; государственные ресурсы защищены в результате ответственного экономического менеджмента на благо всего населения.

- Политическая умеренность и подотчетность есть условие, выражающееся в том, что правительство позволяет политическое улаживание разногласий; основные недовольства разрешаются путем дебатов, компромисса и инклюзивного национального диалога; управляет переменами, порожденными гуманитарными, экономическими, связанными с безопасностью и другими проблемами. Национальный конституционный процесс приводит к разделению властей и способствует формированию сдержек и балансов; выбор лидеров определяется в результате инклюзивного процесса; законодательная власть отражает интересы населения и выборные процессы являются свободными и честными.

- Участие и расширение правомочий гражданского общества является условием, состоящее в том, что существует гражданское общество и оно имеет правомочия, находится под защитой и подотчетно; существуют СМИ, они профессиональны и независимы от правительства или политического влияния; обеспечены равный доступ к информации и свобода выражения; могут формироваться свободно политические партии и они находятся под защитой закона.

- Макроэкономическая стабилизация означает, что сформированы денежно-кредитная и налоговая политика для согласования курса национальной валюты с рыночными уровнями, инфляция находится под контролем и созданы прозрачные и подотчетные системы для менеджмента публичных финансов. Это условие требует прочной и применимой законодательной и регуляторной рамки для управления таких вопросов, как права собственности, коммерция, налоговые операции и прямые иностранные инвестиции. 
- Контроль над подпольной экономикой и экономически обусловленными угрозами миру означает, что подпольное богатство не определяет, кто будет находиться у власти, предотвращается разграбление государственных ресурсов хищническими акторами, бывшие участники боевых действий реинтегрированы, у них есть работа и им предоставляются льготы; природные ресурсы находятся в подотчетном управлении.

- Устойчивость рыночной экономики - обеспечены условия для существования и процветания основанной на рыночных отношениях экономики. Строится или восстанавливается инфраструктура, лелеются и укрепляются частный сектор и человеческий капитал.

- Создание занятости означает, что имеются возможности для создания рабочих мест с целью оказать влияние на ускорение прогресса и приема на работу молодых людей призывного возраста, и имеется прочная база для создания возможностей для зарабатывания средств к существованию.

- Доступ к услугам и предоставление услуг для удовлетворения основных потребностей - населению обеспечен равный доступ к услугам и оно может получать достаточно воды, продовольствия, жилья и медицинских услуг для обеспечения его выживания и ведения достойной жизни. Эти услуги должны предоставляться образом, который обеспечивает их надежность и устойчивость.

- Доступ к образованию и обеспечение образования - у населения имеется равный и постоянный доступ к качественному регулярному и нерегулярному образованию, которое гарантирует развитие и пропагандирует миролюбивое сосуществование. Это условие включает развитие и реформирование всей системы и одинаковый доступ к адекватному, качественному и чувствительному к конфликту образованию.

- Возвращение и расселение беженцев и внутренних перемещенных лии - лица, перемещенные из своих домов в результате вооруженного конфликта, имеют возможность безопасно, добровольно и достойным образом вернуться в свои дома или в новые общины для расселения; имеются механизмы реституции или компенсации; они получают поддержку для реинтеграции и реабилитации, чтобы заново построить свою жизнедеятельность и принимать участие в долгосрочном развитии.

- Социальная реконструкция - население имеет возможность сосуществовать мирным образом через разные формы внутригруппового и межгруппового примирения, - включая механизмы, которые разрешают ненасильственным образом споры и проблему наследства прошлых обид, -и через формирование коммунальных институций, которые сплачивают общество, преодолевая прошлое разделение.

Устойчивая экономика - наличие условий для того, чтобы люди могли использовать возможности для получения средств к существованию в рамках системы экономического управления, соблюдающей закон. Хотя НАТО не обязательно занимается поощрением макроэкономической ста- 
бильности в правовом или регуляторном смысле, у него есть возможность содействовать принимающему государству в осуществлении контроля над его сухопутными и морскими границами для борьбы с незаконной экономикой и нелегальными миграционными сетями. Кроме того, НАТО обычно помогает на начальных этапах в обеспечении безопасности национальной ресурсной инфраструктуры до того, как будут созданы собственные способности государства для этого. В краткосрочном плане, безопасность этих двух секторов способствует возвращению иностранных и местных частных фирм, восстановлению рыночной экономики и дает государству доход, который необходим для расширения его влияния и управленческого потенциала.

Социальное благоденствие - условия для того, чтобы люди были свободными от забот по удовлетворению своих основных потребностей и чтобы могли сосуществовать мирно в обществе, где обеспечены возможности для развития. Наиболее существенно НАТО может способствовать в этом плане через свою способность перемещать людей и оборудование на большие расстояния в короткие сроки. НАТО может поддерживать подвергающееся рискам население, способствуя удовлетворению его базовых потребностей и предоставлению базовых услуг и созданию медицинских учреждений и временного жилья для возвращающихся беженцев.

\section{Приложение С. Рекомендации, не связанные с определенным} вариантом

\section{Соединенные Штаты как ведущее государство}

Часто обмен информацией происходит между сторонами, у которых существует асимметрия в плане их могущества. Меньшие стороны в соглашении по обмену информацией должны позволить тем, кто более могуществен, большую степень влияние и контроля над процессом обмена с тем, чтобы обеспечить их участие в соглашении. ${ }^{56}$ Любая новая рамка для обмена информацией будет нуждаться в участии и ресурсах Соединенных Штатов. Чтобы обеспечить успех какой бы то ни было рамки, ведущую роль должно предоставить Соединенным Штатам.

Штаб-квартира НАТО по специальным операциям (ШНСО) является моделью руководящей роли США в совместных проектах. В 2006 году Соединенные Штаты сыграли критически важную роль в трансформировании канцелярии из трех человек в функционирующий штаб. Соединенные Штаты предоставили персонал для наиболее важных должностях в ШНСО, а затем обеспечили большую часть денег для его ежедневного функционирования. Так как структура ШНСО устанавливала соответствие между мощью и

56 Björn Fägersten, "For EU Eyes Only? Intelligence and European Security," European Union, Institute for Security Studies, March 4, 2016, https://www.iss.europa.eu/ content/eu-eyes-only-intelligence-and-european-security. 
надежностью Соединенных Штатов в специальных операциях и их влиянием в ШНСО, Соединенные Штаты могли формировать доктрины и держать остальных членов подответственными за выполнение требований ШНСО и участии в необходимой подготовке. ${ }^{57}$

Соединенным Штатам следовало бы использовать свои опыт с ШНСО в качестве образца для создания успешного режима обменом информацией в НАТО. Разведывательное сообщество США обеспечено ресурсами в большей степени, чем любой другой член НАТО, и оно может предложить необходимые доктрины и рекомендации. Назначение американского персонала на должности в разведывательном аппарате НАТО даст большую степень единства усилий и приведет к ускорению утверждения структуры.

Недостатки этого варианта проявляются на национальном уровне для стран-членов. Во-первых, правительство Соединенных Штатов должно быть убеждено в необходимости расходов на подготовку и оборудование. Другим источником разногласий могут стать опасения властей других странчленов, касающиеся увеличенного обмена информацией между ними самими. Соединенные Штаты могут быть убеждены в необходимости этих мер, если будут рассматривать эти инвестиции в качестве фактора, повышающего эффективность сил в будущих операциях. Способность быстрее обмениваться информацией как на оперативном, так и на стратегическом уровне, улучшит ведение операций альянса вне его территории. Разведывательное сообщество США будет предоставлять тот же объем разведданных, который оно уже предоставляет НАТО. Разница в том, что каналы обмена гораздо лучше будут понятны всем другим участникам и гораздо выше будет вероятность реципрокного потока, поскольку другие участники будут лучше подготовлены к процессу предоставления разведданных. Препятствия, проистекающие из нежелания стран-членов расширять обмен, могут быть преодолены с использованием руководящей роли США в текущей разведывательной структуре НАТО. США производят большую часть всех разведданных альянса и могут использовать этот факт для убеждения других членов оптимизировать процессы обмена, которые уже используются.

\section{Гражданский директор разведки}

Назначение Помощника генерального секретаря НАТО по разведке создаст должность на высшем уровне, которая улучшила бы разведывательные операции и обмен данными путем преодоления некоторых структурных недостатков в альянсе. Создание главной должности по разведке, эквивалентной должности трехзвездного генерала, могла бы обеспечить покровительство над обменом разведданных между невоенными и военными разведывательными организациями НАТО. Эта должность так же обеспечит плат-

57 Martin J. Ara, Thomas Brand, and Brage A. Larssen, Help a Brother Out: A Case Study in Multinational Intelligence Sharing, NATO SOF, Master's Thesis (Monterey, CA: Naval Postgraduate School, 2011), цитата на c. 40-41, https://calhoun.nps.edu/bitstream/ handle/10945/10727/11Dec_Ara.pdf. 
форму на высшем уровне для уменьшения растраты ресурсов, проистекающей из соперничества и дублирования усилий в текущей разделенной системе. В настоящее время есть семь помощников секретаря с портфелями от публичной дипломатии и исполнительного менеджмента до оборонных инвестиций и новых вызовов безопасности. ${ }^{58}$ Эти вопросы были сочтены критически важными для функционирования альянса, и отсутствие эффективного надзора над разведкой тоже является критической проблемой, мешающей единству усилий на оперативном и на стратегическом уровнях.

Ключевым неблагоприятным фактором для обмена разведданными между странами-членами НАТО является то, что распространение осуществляется на национальной основе в соответствии с национальной политикой, а не как совместная работа под эгидой альянса. ${ }^{59}$ Другим препятствием перед обменом информацией является разъединенный характер поставщиков разведданных для альянса. Североатлантический совет (САС) и Военный комитет (ВК) обеспечиваются отдельными субъектами: Разведывательным подразделением (РП) и Международным военным штабом разведывательным управлением (МВШ-РУ), соответственно. РП собирает свои разведданные через гражданские национальные разведывательные службы на двусторонней основе, которые затем предоставляются гражданским властям НАТО в САС. ${ }^{60}$ Перед МВШ-РУ стоит задача ежедневного предоставления стратегических разведданных всем элементам штаб-квартиры и командованиям НАТО и получает свои разведданные как от вооруженных сил стран-членов, так и от командований НАТО. ${ }^{61}$

В настоящее время единственной структурой для интеграции этих двух органов является Руководящий совет по разведке, который входит в сферу ответственности заместителя Генерального секретаря. Ни Руководящий совет, ни заместитель Генерального секретаря не могут обеспечить требуемое руководство разведывательных операций альянса. У заместителя Генерального секретаря множество обязанностей и надзор за разведкой только одна из них, а сам заместитель обычно не имеет опыта разведывательной работы. Руководящий совет по разведке обычно заседает от шести до восьми раз в год для определения реакции на конкретные проблемы и не предназначен для оперативного руководства. ${ }^{62}$ Должность специального помощника Генерального секретаря по разведке будет обеспечивать постоянное присутствие профессионала по разведке на верхнем уровне руководства. Этот пост будет постоянным средством для интеграции усилий разведывательных служб НАТО, а также ему будут предоставлены полномочия про-

58 "Principal Officials," North Atlantic Treaty Organization, August 25, 2015, http://www.nato.int/cps/po/natohq/who_is_who_51639.htm.

59 Интервью в СКБР, 14-15 марта 2016.

60 Интервью с источником К, представитель МО США, 16 марта 2016.

61 North Atlantic Treaty Organization, "International Military Staff," January 6, 2015, http://www.nato.int/cps/en/natohq/topics_64557.htm.

62 Интервью с источником N, 17 марта 2016. 
двигать необходимые структурные реформы и обеспечивать место для стратегического планирования разведки.

Наиболее существенным недостатком этого варианта является создание еще одной большой бюрократической организации. НАТО работает в условиях финансовых ограничений и какие-либо новые существенные расходы будут встречены в штыки как структурами НАТО, так и странами-членами. Вероятно, по этой причине после террористических нападений от 11 сентября создаются меньшие и более локально ориентированные структуры в виде РП и МВШ-РУ. Эти денежные расходы могут быть уменьшены, если на новые должности будут назначаться люди, уже служащие в разведывательных органах НАТО, поскольку их организации уже перейдут под опеку канцелярии ПГС. Другим существенным препятствием перед реформой разведки НАТО будут национальные интересы стран-членов и, если мы хотим, чтобы национальные разведывательные органы приняли это предложение, надо будет подготовить обстоятельный дискурс по этому вопросу. ${ }^{63}$

\section{Операционализация штабов по разведке}

В процессе нашего исследования было установлено, что совместные отделы по разведке в оперативных управлениях J2 и G2 при штаб-квартире НАТО недостаточно подготовлены для функционирования в сложной среде, в которой находится альянс. Приведение в оперативную готовность этих отделов по разведке потребует проведения определенных реформ. В их число входят увеличение численности личного состава, предназначенного для сбора и анализа разведданных, обеспечение более всеохватного и более практического обучения, интегрирование улучшенных реальных сценариев в штабных учениях и обеспечение интегрирования этих штабов в структуры НАТО или в рамку национальных разведывательных структур.

В нашем исследовании было установлено, что констатация о недостаточной подготовке с особой силой относится для девяти штаб-квартир высокой готовности для корпусов быстрого развертывания НАТО. Эти корпуса являются частью Сил реагирования НАТО (СРН) - совместных вооруженных сил, которые могут быть развернуты в кратчайшие сроки там, где это нужно. Каждый корпус участвует в системе ротации СРН, в рамках которой он приводится в состояние повышенной готовности на 12 месяцев, и пока находится в этом статусе, он отвечает за командование сухопутного компонента СРН. ${ }^{64}$ Эти корпуса имеют центральное значение для операций НАТО. Союзный корпус быстрого реагирования (СКБР), к примеру, служил штаб-квартирой для осуществляемых под руководством НАТО миссий в Боснии и Герце-

63 Brian R. Foster, Enhancing the Efficiency of NATO Intelligence Under an ASG-I, Strategy Research Project (United States Army War College, March 2013), цитата на стр. 2728.

64 North Atlantic Treaty Organization, "Rapid Deployable Corps," November 9, 2015, по состоянию на 28 марта 2016, www.nato.int/cps/sl/natohq/topics_50088.htm. 
говине, Косово, два раза в Афганистане и был ментором для двух совместных штаб-квартир в Ираке в 2008 году. ${ }^{65}$ Набор задач, которые были призваны выполнять штабы НАТО, варьировал от операций по борьбе с пиратством, обеспечению безопасности границ и охранению мира до многонациональных кампаний по борьбе с повстанцами. Все эти миссии требуют как углубленного понимания общей обстановки, так и наличия своевременных разведданных, касающихся противоборствующих сил. Но разведывательные отделы не получают подготовки и ресурсов, которые нужны, когда они не находятся на ротационном дежурстве в качестве единственной штабквартиры СРН.

Первой причиной для недостаточного обеспечения ресурсами является институциональная и поведенческая предрасположенность разведывательных организаций НАТО на первом месте обращать внимание на стратегический уровень планирования. ${ }^{66}$ Этот настрой, понятный на союзном уровне, не обеспечивает подготовку аналитиков для работы в полевых условиях, которую от них ожидают. Учения, как например Trident Jaguar, хотя оказались эффективными при разработке и интернализации стандартных оперативных процедур для разведывательных отделов, не дают требуемой базы умений для разведывательной работы в реальных условиях, за развертывание которой отвечают разведывательные отделы. ${ }^{67}$ Другой проблемой, с которой сталкиваются разведывательные отделы, является то, что вооруженные силы некоторых стран-членов не развертывают специальные разведывательные формирования, и поэтому личный состав, придаваемый совместным отделам, часто не имеет даже рудиментарного понимания разведывательного процесса. 68

Основным недостатком этого варианта является цена. Надо найти денег для нахождения, принятия на работу, оборудования и, наконец, подготовку аналитиков и персонала для расширенных штабных отделов. Время тоже является фактором, с которым надо считаться, поскольку процесс расширения и всю необходимую подготовку нельзя закончить за один день. Операционализация потребует увеличения численности личного состава для компенсации увеличенной рабочей нагрузки, с которой этому личному составу придется справляться. Увеличение численности персонала облегчит переход от состояния покоя к оперативной готовности путем привыкания персонала к более широкому и быстрее меняющемуся окружению. Персонал приобретет жизненно важный опыт в результате анализа разведданных из реального мира и увеличит свою эффективность путем практического вы-

65 Allied Joint Force Command, "Previous Operations," по состоянию на 28 марта 2016, http://www.arrc.nato.int/operations/previous.

66 Foster, Enhancing the Efficiency of NATO Intelligence, 3-7.

67 Интервью с источником J, 14 марта 2016.

68 Интервью с источниками E, F, G и M, 14-15 марта 2016. 
полнения стандартных оперативных процедур на постоянной основе. ${ }^{69}$ Учения для всего штаба станут более реалистическими в результате того, что личный состав будет работать с текущими и реальными разведданными, которые будет анализировать разведывательное отделение. ${ }^{70}$ Такое приведение в состояние оперативной готовности также даст возможность для расширения аналитической ленты частот как для НАТО, так и для участвующих национальных вооруженных сил, поскольку их служащие будут иметь возможность стать специалистами по данному вопросу в результате ежедневной работы с определенными наборами разведданных ${ }^{71}$ Хотя и являющийся дорогостоящим, этот вариант создаст национальных специалистов по разведке, которые вернутся в свои страны после завершения командировки с опытом не только в реализации своей национальной политики в области разведки, но и с целостным пониманием совместного разведывательного процесса.

69 Интервью с источником В, 15 марта 2016.

70 Интервью с источником J, 14 марта 2016.

71 Интервью с бригадным генералом Джосеф О'Салливан, начальником отдела G-2 СКБР НАТО, 15 марта 2016. 